\title{
PENGARUH MINUMAN KARBOHIDRAT ELEKTROLIT TERHADAP PRODUKTIVITAS KERJA
}

\author{
Oqi Bintang Hapsari, Apoina Kartini ${ }^{*}$ \\ Program Studi Ilmu Gizi Fakultas Kedokteran Universitas Diponegoro \\ Jl.Dr.Sutomo No.18, Semarang, Telp (024) 8453708, Email : gizifk@undip.ac.id
}

\begin{abstract}
Background : Productivity of work into the image of the effectiveness and efficiency of an industry in total employment. Labor productivity of each person was different, one of which depends on adequacy of energy and fluid intake was beneficial to avoid fatigue during the work. The aimed of this study to determined the effect of isotonic drink on work productivity in garment workers sew sections aged 18-40 years old.

Methods : Pre-experimental study with pretest-posttest one group design in 35 garment workers sew section aged 18-40 years old at CV. X Semarang in July 2013. Posttest group received $250 \mathrm{ml}$ carbohydrate electrolyte drink before work and during breaks, while pretest group was not given carbohydrate electrolyte drink. Both groups work productivity is calculated based on the results of stitches per hour for 3 days.

Results : The mean result of posttest group was higher than pretest group $(131,26 \pm 23,45$ seed/hour versus 116,34 $\pm 25,8$ seed/hour). Carbohydrate electrolyte drink affected work productivity after controlling fluid intake, energy intake and age $(p=0,008)$. Carbohydrate electrolyte drink increased the number of productive workers from $14.28 \%$ to $45.71 \%$.

Conclusion : Carbohydrate electrolite drink affected work productivity after controlling fluid intake, energy intake and age among garment workers sew sections aged 18-40 years old.
\end{abstract}

Keyword : carbohydrate electrolyte drink; work productivity.

\section{ABSTRAK}

Latar Belakang : Produktivitas kerja menjadi gambaran efektifitas dan efisiensi kerja secara total suatu industri. Produktivitas kerja setiap orang berbeda-beda, salah satunya tergantung dari kecukupan asupan energi dan cairan yang bermanfaat untuk menghindari kelelahan selama bekerja. Tujuan penelitian ini untuk mengetahui pengaruh minuman karbohidrat elektrolit terhadap produktivitas kerja pada pekerja garmen bagian menjahit berusia 18-40 tahun.

Metode : Studi pra eksperimental dengan rancangan pre test - post test one group design pada 35 pekerja garmen bagian menjahit berusia 18-40 tahun di CV. X Semarang pada bulan Juli 2013. Kelompok posttest mendapat minuman karbohidrat elektrolit sebanyak $250 \mathrm{ml}$ saat sebelum bekerja dan saat jam istirahat, sedangkan pada kelompok pretest tidak diberi minuman karbohidrat elektrolit. Kedua kelompok dilihat produktivitas kerjanya berdasarkan hasil jahitan per jam selama 3 hari.

Hasil : Rerata hasil kerja kelompok posttest lebih tinggi dari kelompok pretest $(131,26 \pm 23,45$ bijiljam berbanding 116,34+25,8 biji/jam). Minuman karbohidrat elektrolit berpengaruh terhadap produktivitas kerja setelah dikontrol asupan cairan, asupan energi dan usia $(p=0,008)$. Minuman karbohidrat elektrolit meningkatkan jumlah pekerja yang produktif dari $14,28 \%$ menjadi $45,71 \%$.

Kesimpulan : Minuman karbohidrat elektrolit berpengaruh terhadap produktivitas kerja setelah dikontrol asupan cairan, asupan energi dan usia pada pekerja garmen bagian menjahit yang berusia 18-40 tahun.

Kata kunci : Minuman karbohidrat elektrolit; produktivitas kerja.

\section{PENDAHULUAN}

Pekerja merupakan segmen populasi penting yang berhubungan dengan produktivitas suatu industri. Jumlah pekerja sektor industri di Indonesia yang tercatat pada Februari 2012 yaitu 14,2 juta orang dan pada Agustus 2012 meningkat menjadi 15,3 juta orang. ${ }^{1}$ Peningkatan jumlah pekerja ini masih belum diimbangi dengan kesehatan kerja di industri, yang berisiko menimbulkan kelelahan fisik dan mempengaruhi kualitas produktivitas kerja. $^{2}$
Produktivitas kerja merupakan suatu konsep universal yang menciptakan lebih banyak barang dan jasa bagi kebutuhan manusia dengan menggunakan sumber daya yang terbatas. Produktivitas kerja menjadi gambaran efektifitas dan efisiensi kerja secara total suatu industri. ${ }^{3}$ Produktivitas kerja yang tinggi dapat terwujud bila adanya kesesuaian antara beban kerja, kapasitas kerja dan beban tambahan akibat lingkungan kerja. ${ }^{4}$ Produktivitas kerja setiap orang berbedabeda, salah satunya tergantung dari tersedianya zat

${ }^{*}$ Penulis Penanggungjawab 
gizi di dalam tubuh. Kekurangan konsumsi zat gizi bagi seseorang dari standar minimum umumnya akan berpengaruh terhadap kondisi kesehatan, aktivitas dan produktivitas kerja. ${ }^{5}$

Kekurangan konsumsi zat gizi yang sering dialami oleh pekerja industri antara lain kekurangan cairan. Tubuh yang kekurangan cairan atau dehidrasi akan ditandai dengan munculnya rasa haus. Ketika pasokan cairan terbatas atau tubuh mengeluarkan banyak cairan, laju kehilangan air melebihi laju kehilangan elektrolit. Cairan ekstraselular menjadi jenuh dan tekanan osmotik menarik air dari cairan intra-selular ke dalam cairan ekstraselular. ${ }^{8}$ Penelitian pada pekerja industri tambang di Australia menunjukkan sebanyak $60 \%$ pekerja mengalami dehidrasi dan status hidrasinya tidak meningkat setelah 10-12 jam berikutnya. ${ }^{6}$ Penelitian pada penebang pohon di Afrika Selatan juga menunjukkan sebanyak 44\% pekerja dalam keadaan dehidrasi saat datang ke tempat kerja. ${ }^{7}$ The National Academy of Science mengkaji beberapa studi tentang pengaruh dehidrasi pada kapasitas kerja fisik. Kajian disimpulkan bahwa kehilangan cairan melebihi $2 \%$ dari berat badan menurunkan kapasitas kerja, dengan menekankan ketika bekerja pada tempat yang panas. ${ }^{10}$ Kapasitas kerja yang menurun menyebabkan penurunan produktivitas kerja. ${ }^{9}$

Dehidrasi yang terjadi selalu disertai dengan perubahan keseimbangan elektrolit. ${ }^{9}$ Pekerja yang bekerja pada suhu lingkungan panas selama 10 hari rata-rata kehilangan antara 4.8 - 6 gram natrium yang setara dengan $12-15$ gram garam (NaCL). ${ }^{11}$ Natrium pada tubuh bertindak sebagai kation utama cairan ekstraselular yang mengendalikan osmolaritas dan volume cairan tubuh. $^{12}$

Pekerja khususnya yang terpapar panas disarankan untuk mengkonsumsi minuman sebanyak $250 \mathrm{ml}$ (setara 1 gelas) setiap 25-30 menit saat bekerja. ${ }^{9}$ Penelitian pada juru masak restauran di Semarang menunjukkan bahwa pemberian minuman formulasi air kelapa sebanyak $400 \mathrm{ml} /$ hari yang mengandung rerata natrium 0.66 $\mathrm{g} / \mathrm{L}$, kalium $0.23 \mathrm{~g} / \mathrm{L}$ dan kadar gula reduksi $7.6 \%$ selama 3 hari dapat memperbaiki kemampuan rehidrasi dan mengurangi kelelahan subjektif. ${ }^{13}$ Natrium pada minuman berfungsi untuk mengganti kehilangan natrium lewat keringat dan bertindak sebagai transport glukosa melewati dinding intestinal. Glukosa yang ditambahkan pada minuman bermanfaat untuk menjaga kadar glukosa darah dan menghindari kelelahan selama bekerja. ${ }^{11}$
Menurut penelitian pekerja bagian ironing industri garmen di kabupaten Semarang pada tahun 2011, menunjukkan bahwa pemberian minuman karbohidrat elektrolit dapat memperbaiki status hidrasi dan mengurangi kelelahan pekerja. ${ }^{14}$

Sebanyak $60 \%$ pekerja di CV. Eterna Garment Semarang memiliki hasil kerja yang belum sesuai target pabrik. Pekerja yang terbiasa beraktivitas pada suhu $\pm 37^{\circ} \mathrm{C}$ memiliki rerata asupan cairan selama bekerja sebesar $835,7 \mathrm{ml}$ atau $40,26 \%$ dari kebutuhan cairan. Berdasarkan latar belakang tersebut, maka ingin dilakukan penelitian untuk mengetahui pengaruh minuman karbohidrat elektrolit terhadap produktivitas kerja.

\section{METODE}

Penelitian ini dilakukan di CV. Eterna Garment Semarang pada bulan Juni 2013. Penelitian ini termasuk lingkup gizi masyarakat dan merupakan studi pra eksperimental dengan rancangan pre test - post test one group design.

Populasi pada penelitian ini yaitu seluruh pekerja garmen bagian penjahit sejumlah 40 orang. Pengambilan subjek diawali dengan melakukan skrining terhadap seluruh pekerja untuk menentukan status gizi. Status gizi ditentukan berdasarkan Indeks Massa Tubuh (IMT), subjek yang memiliki IMT $18.5 \mathrm{~kg} / \mathrm{m}^{2}$ sampai $22.9 \mathrm{~kg} / \mathrm{m}^{2}$ dikategorikan normal. Menurut perhitungan jumlah sampel subjek yang dibutuhkan sebanyak 35 orang. Subjek diambil dengan cara consecutive sampling. Kriteria inklusi yaitu pekerja garmen bagian penjahit berusia 18-40 tahun, IMT normal, tidak mengkonsumsi suplemen yang meningkatkan ketahanan tubuh.

Data yang dikumpulkan dalam penelitian ini adalah identitas subjek, status gizi berdasarkan IMT, produktivitas kerja, recall asupan makan dan recall asupan cairan. Produktivitas kerja adalah total celana yang dijahit pekerja tiap jam. Produktivitas kerja dikategorikan produktif (hasil kerja $\geq 130$ celana/jam) dan kurang produktif (hasil kerja $<130$ celana/jam). Minuman karbohidrat elektrolit yang digunakan yakni minuman dalam kemasan yang mengandung 5\% karbohidrat jenis high fructose corn syrup dan maltodextrin, natrium 5\% (126 mg), kalium $43 \mathrm{mg}$, kalsium $38 \mathrm{mg}$ dalam $250 \mathrm{ml}$, yang diberikan sebanyak $250 \mathrm{ml}$ sebelum jam bekerja dan $250 \mathrm{ml}$ saat jam istirahat.

Asupan energi yakni jumlah asupan energi rata-rata yang dikonsumsi pekerja selama 3 hari diukur dengan metode food recall 24 jam. Pengambilan data dilakukan dengan wawancara 
terhadap responden. Data dihitung dalam bentuk URT (ukuran rumah tangga) yang dikonversikan ke dalam satuan gram kemudian dihitung nilai energinya menggunakan NutriSurvey. Hasil analisis rata-rata asupan energi dibandingkan dengan kebutuhan energi individu kemudian dikalikan $100 \%$, maka didapatkan persen tingkat konsumsi energi. Tingkat asupan energi dibagi menjadi tiga kategori yaitu kurang $(<80 \%)$, baik $(80-100 \%)$, dan lebih $(>100 \%){ }^{15}$

Asupan cairan yakni jumlah asupan cairan rata-rata yang dikonsumsi pekerja selama 3 hari diukur dengan metode food recall $3 \times 24$ jam. Asupan cairan yang dihitung yakni minuman karbohidrat elektrolit yang diberikan dan minuman lain yang dikonsumsi pekerja per hari. Data dihitung dalam bentuk URT kemudian dikonversi dalam satuan ml. Jumlah konsumsi cairan kemudian dibandingkan dengan kebutuhan cairan menurut berat badan.

Pengolahan dan analisis data menggunakan program komputer. Data diuji normalitasnya dengan menggunakan Shapiro-wilk.
Untuk mengetahui perbedaan produktivitas kerja pada kelompok pretest dan kelompok posttest, karena data tidak normal digunakan uji Mannwhitney. Untuk mengetahui perbedaan asupan energi dan asupan cairan antara kedua kelompok, karena data normal digunakan uji independent $t$ test. Uji analisis Ancova digunakan untuk melihat pengaruh variabel bebas terhadap variabel terikat setelah dikontrol variabel perancu.

\section{HASIL PENELITIAN}

Jumlah pekerja di CV. Eterna Garment sebanyak 50 orang yang dalam sehari bekerja selama 8 jam. Pekerja terbiasa bekerja di pabrik yang memiliki suhu ruang $\pm 37^{\circ} \mathrm{C}$. Menurut hasil penyaringan awal diketahui prevalensi pekerja yang kurang produktif sebesar 60\%. Jumlah subjek penelitian yang memenuhi syarat inklusi sebanyak 35 orang.

\section{Karakteristik Subjek Penelitian}

Subjek pada penelitian ini wanita yang berusia antara 18-40 tahun dengan rerata $28 \pm 6,93$ tahun. Rerata IMT subjek yaitu $21,3 \pm 1,35 \mathrm{~kg} / \mathrm{m}^{2}$.

Tabel 1. Karakteristik subjek menurut usia, IMT, persentase asupan energi, asupan cairan dan hasil kerja

\begin{tabular}{lccc}
\hline \multirow{2}{*}{ Karakteristik subjek } & \multicolumn{3}{c}{ Sebelum intervensi } \\
\cline { 2 - 4 } & Min & Maks & rerata \pm SD \\
\hline Usia (tahun) & 18 & 40 & $28 \pm 6,93$ \\
Berat badan $(\mathrm{kg})$ & 38,9 & 60 & $48,9 \pm 5$ \\
Tinggi badan $(\mathrm{cm})$ & 143,2 & 162 & $151,2 \pm 4,49$ \\
IMT $\left(\mathrm{kg} / \mathrm{m}^{2}\right)$ & 18,5 & 22,8 & $21,3 \pm 1,35$ \\
Persentase asupan energi (\%) & 39 & 164 & $106,7 \pm 31,22$ \\
Persentase asupan cairan (\%) & 52 & 108 & $78 \pm 11,61$ \\
Hasil kerja pretest $($ celana/jam) & 77 & 210 & $116,34 \pm 25,85$ \\
\hline
\end{tabular}

\section{Asupan Energi dan Asupan Cairan}

Berdasarkan tabel 2, menunjukkan bahwa tidak terdapat perbedaan asupan energi antara sebelum intervensi dan setelah intervensi $(\mathrm{p}=$ $0,084)$. Sedangkan asupan cairan antara sebelum intervensi dan setelah intervensi terdapat perbedaan $(\mathrm{p}=0,000)$, yakni dengan rerata asupan cairan ketika setelah intervensi sebesar 1966 $\pm 209,3$ $\mathrm{ml}$ dan rerata asupan cairan saat sebelum intervensi sebesar $1616 \pm 239,3 \mathrm{ml}$.

Tabel 2. Asupan energi dan cairan antara sebelum intervensi dan setelah intervensi

\begin{tabular}{|c|c|c|c|c|c|c|c|}
\hline & \multicolumn{3}{|c|}{ Sebelum intervensi $(n=35)$} & \multicolumn{3}{|c|}{ Setelah intervensi $(n=35)$} & \multirow{2}{*}{$\mathrm{p}$} \\
\hline & Min & maks & rerata $\pm \mathrm{SD}$ & $\min$ & maks & rerata \pm SD & \\
\hline $\begin{array}{l}\text { Asupan energi } \\
\text { (kkal) }\end{array}$ & 486,8 & 1902,4 & $1203 \pm 349,8$ & 723,33 & 1947,93 & $1339 \pm 296$ & 0,084 \\
\hline $\begin{array}{l}\text { Persentase asupan } \\
\text { energi }(\%)\end{array}$ & 39 & 164 & $106,7 \pm 31,22$ & 55 & 166 & $119,2 \pm 28,8$ & \\
\hline \multirow{3}{*}{$\begin{array}{l}\text { Asupan cairan }(\mathrm{ml}) \\
\text { Persentase asupan } \\
\text { cairan }(\%)\end{array}$} & & & & & & & \\
\hline & 1133,46 & 2282,85 & $1616 \pm 239,3$ & 1653,96 & 2461,28 & $1966 \pm 209,3$ & 0,000 \\
\hline & 52 & 108 & $78 \pm 11,61$ & 75 & 115 & $95 \pm 11,3$ & \\
\hline
\end{tabular}




\section{Kepatuhan Konsumsi Minuman Karbohidrat Elektrolit}

Sebanyak 21 orang yang menghabiskan $>75 \%$ minuman karbohidrat elektrolit memiliki rerata hasil kerja 134,33 $\pm 27,47$ celana/jam dan 14 orang menghabiskan $50 \%-75 \%$ minuman karbohidrat elektrolit memiliki rerata hasil kerja $126,64 \pm 15,44$ celana/jam. Berdasarkan tabel 3 menunjukkan bahwa tidak ada perbedaan $(\mathrm{p}=0,866)$ hasil kerja antara pekerja yang menghabiskan minuman karbohidrat elektrolit $>75 \%$ dan $50-75 \%$.

Tabel 3. Kepatuhan menghabiskan minuman karbohidrat elektrolit

\begin{tabular}{lcccc}
\hline & \multicolumn{3}{c}{ Hasil kerja (celana/jam) } & \multirow{2}{*}{ P } \\
\cline { 2 - 4 } & min & maks & rerata \pm SD & \\
\hline Persentase habisnya minuman & & & & 0,866 \\
karbohidrat elektrolit & 93 & 154 & $126,64 \pm 15,44$ & \\
$50-75 \%$ & 92 & 216 & $134,33 \pm 27,47$ & \\
$>75 \%$ & & & & \\
\hline
\end{tabular}

\section{Pengaruh Minuman Karbohidrat Elektrolit terhadap Produktivitas Kerja}

Rerata hasil kerja pada pekerja setelah diberi minuman karbohidrat elektrolit lebih banyak $(131,26 \pm 23,45$ celana/jam) dibanding sebelum diberi minuman karbohidrat elektrolit $(116,34 \pm 25,85$ celana/jam). Terdapat perbedaan produktivitas kerja antara sebelum diberi intervensi dan setelah diberi intervensi $(p=0,004)$.

Tabel 4. Hasil kerja antara sebelum intervensi dan setelah intervensi

\begin{tabular}{|c|c|c|c|c|c|}
\hline & \multicolumn{4}{|c|}{ Hasil kerja (celana/jam) } & \multirow{2}{*}{$\mathrm{p}$} \\
\hline & $\mathrm{n}$ & $\min$ & maks & rerata $\pm \mathrm{SD}$ & \\
\hline Sebelum intervensi & 35 & 77 & 210 & $116,34 \pm 25,85$ & 0,004 \\
\hline Setelah intervensi & 35 & 92 & 216 & $131,26 \pm 23,45$ & \\
\hline
\end{tabular}

Berdasarkan hasil analisis uji Ancova, variabel asupan cairan memiliki nilai $\mathrm{p}=0,587$ dan variabel asupan energi memiliki nilai $\mathrm{p}=0,293$ yang berarti tidak ada hubungan linier antara asupan cairan dan asupan energi dengan produktivitas kerja. Variabel usia memiliki nilai $\mathrm{p}=0,027$ yang berarti ada hubungan linier antara usia dengan produktivitas kerja. Variabel minuman karbohidrat elektrolit memiliki nilai $\mathrm{p}=0,232$ yang berarti tidak ada pengaruh minuman karbohidrat elektrolit terhadap produktivitas kerja. Corrected model pada uji Ancova ini memiliki nilai $\mathrm{p}=0,008$ yang menunjukkan bahwa minuman karbohidrat elektrolit berpengaruh terhadap produktivitas kerja setelah dikontrol asupan cairan, asupan energi dan usia.

\section{PEMBAHASAN}

\section{Karakteristik Subjek}

Pekerja yang kurang produktif saat belum diberi intervensi pada penelitian ini sebesar $85,71 \%$ dengan usia pekerja berkisar 18-40 tahun. Distribusi jumlah pekerja yang kurang produktif pada kelompok usia < 30 tahun sebanyak 17 subjek
$(48,5 \%)$ dan pada kelompok usia 30-40 tahun sebanyak 13 subjek $(37,1 \%)$. Survei penelitian di Jerman menyatakan seseorang memiliki tingkat produktivitas kerja paling tinggi saat berusia 30-40 tahun, kemudian akan mulai menurun pada usia 50 tahun. Seseorang pada usia 30 tahunan memiliki puncak perkembangan fisik dan kekuatan fisik yang dapat mendukung dalam bekerja. ${ }^{16}$

Asupan energi yang cukup pada pekerja diperlukan untuk metabolisme tubuh. Karbohidrat yang merupakan sumber energi terbesar diubah menjadi glukosa. Glukosa mengalami glikolisis di sitosol yang menghasilkan asam piruvat, kemudian piruvat dioksidasi menjadi asetil koA di mitokondria. Asetil koA memasuki siklus asam sitrat yang menghasilkan molekul ATP (adenosin trifosfat) yang merupakan sumber energi sel-sel tubuh. $^{17}$ Seseorang memiliki kategori asupan energi baik bila asupannya mencapai $80-100 \%$ dari kebutuhan dan kategori asupan energi kurang bila asupan energinya kurang dari $80 \%$ kebutuhan. ${ }^{15}$ Sebanyak 6 subjek $(17 \%)$ pada penelitian ini memiliki kategori asupan energi kurang saat belum diberi intervensi. 
Pekerja yang aktif bekerja pada lingkungan panas dianjurkan mengkonsumsi minuman sebanyak $250 \mathrm{ml}$ atau satu gelas setiap 20-30 menit secara teratur, karena ketika bekerja pada suhu lingkungan yang panas menyebabkan suhu tubuh meningkat sehingga dihasilkan pula keringat yang lebih banyak. ${ }^{9,18}$ Keringat yang banyak keluar tanpa asupan cairan yang cukup dapat menimbulkan volume cairan tubuh berkurang, khususnya pada cairan ekstraselular. Cairan ekstraselular yang berkurang akan meningkatkan osmolalitas plasma, kemudian respon ini diterima oleh baroreseptor di sistem saraf pusat yang merangsang produksi ADH (anti diuretic hormone) di hipotalamus dan dilepas ke sirkulasi darah. ADH akan menurunkan permeabilitas sel-sel tubulus distal ginjal yang meningkatkan reabsorbsi cairan. Volume cairan tubuh meningkat dan mengembalikan osmolalitas plasma menjadi normal. Hal inilah yang menyebabkan urin menjadi lebih pekat. ${ }^{19}$ Tubuh secara bersamaan juga memunculkan respon berupa rasa haus ketika mengetahui cairan tubuh telah berkurang. ${ }^{18}$ Untuk mencegahnya, asupan cairan pada pekerja perlu disesuaikan dengan kebutuhan cairan yang dapat diketahui menurut berat badannya. ${ }^{20}$ Pekerja pada penelitian ini terbiasa bekerja selama 8 jam pada pabrik yang memiliki suhu $\pm 37^{\circ} \mathrm{C}$. Setelah dibandingkan dengan kebutuhan tiap subjek, sebanyak 33 subjek (94\%) asupan cairannya masih kurang dari kebutuhan saat belum diberi intervensi.

\section{Pengaruh Minuman Karbohidrat Elektrolit terhadap Produktivitas Kerja}

Penelitian ini menggunakan minuman karbohidrat elektrolit yang mengandung 5\% karbohidrat jenis high fructose corn syrup dan maltodextrin, $126 \mathrm{mg}$ natrium, $43 \mathrm{mg}$ kalium dan $38 \mathrm{mg}$ kalsium. Minuman karbohidrat elektrolit yang digunakan sesuai dengan karakteristik minuman karbohidrat elektrolit yaitu mengandung karbohidrat $5 \%-7 \%$ atau 14 gr dalam $250 \mathrm{ml}$ dengan jenis karbohidrat yang indeks glikemiknya tinggi dan 110-165 mg natrium. ${ }^{20}$ Jenis karbohidrat yang biasa terkandung dalam minuman isotonik yaitu karbohidrat sederhana (seperti glukosa, fruktosa, sukrosa) dan karbohidrat kompleks (seperti high fructose corn syrup, maltodextrin, corn sweetener). ${ }^{21} \quad$ Kandungan karbohidrat minuman karbohidrat elektrolit yang dianjurkan yakni 5\% - 8\%. Peningkatan konsentrasi karbohidrat di atas $8 \%$ dalam minuman karbohidrat elektrolit selain menimbulkan risiko penundaan laju pengosongan lambung, juga meningkatkan ketidaknyamanan dalam perut. ${ }^{22}$

Menurut hasil analisis uji Mann Whitney terdapat perbedaan produktivitas kerja antara sebelum intervensi dan setelah intervensi $(\mathrm{p}=0,004)$. Selain itu hasil analisis uji Ancova menunjukkan bahwa pemberian minuman karbohidrat elektrolit berpengaruh terhadap produktivitas kerja setelah dikontrol asupan cairan, asupan energi dan usia $(\mathrm{p}=0,008)$. Penelitian di Semarang juga menyatakan bahwa pemberian minuman karbohidrat elektrolit dapat memperbaiki status hidrasi dan mengurangi kelelahan pada pekerja bagian ironing industri garmen. ${ }^{14}$

Hal ini disebabkan kandungan karbohidrat (high fructose corn syrup dan maltodextrin) dalam minuman karbohidrat elektrolit yang telah dimetabolisme menjadi glukosa dapat digunakan sebagai sumber energi tubuh. Kelebihan asupan glukosa akan diubah menjadi glikogen yang disimpan pada hati dan otot. Glikogen hati berfungsi untuk menjaga kadar glukosa darah yang menyediakan energi secara konstan ke otot dan jaringan tubuh lain. Glikogen otot yang ada digunakan sebagai sumber energi untuk aktivitas tubuh. $^{23,21}$

Selain karbohidrat, elektrolit utama seperti natrium dan kalium yang hilang bersama cairan dan keringat saat beraktivitas dapat digantikan melalui konsumsi minuman karbohidrat elektrolit. Natrium berfungsi untuk membantu absorbsi glukosa di usus halus. ${ }^{22}$ Kalium bekerja sama dengan natrium menjaga keseimbangan cairan dan elektrolit. $^{21}$ Glukosa dan elektrolit ini akan berinteraksi dalam dinding usus (epitelium mukosa usus halus proximal), glukosa akan menstimulasi absorbsi elektrolit dan elektrolit juga dibutuhkan untuk mengabsorbsi glukosa. Kerja sama antara glukosa dan elektrolit ini meningkatkan osmolalitas sehingga larutan cenderung pekat. Absorbsi elektrolit dan glukosa dari usus ke sirkulasi darah dibantu oleh transporter, sedangkan air melalui difusi pasif. ${ }^{24,17}$

Pekerja yang biasa bekerja pada suhu panas mengalami peningkatan reabsorbsi natrium di tubulus kelenjar keringat, sebagai respon adaptif yang membantu melindungi volume plasma dengan menurunkan kehilangan natrium. Kadar natrium dalam tubuh yang cukup selama beraktivitas dapat membantu mendorong asupan cairan, menjaga volume plasma dan mengurangi produksi urin. ${ }^{25}$

Menurut hasil analisis uji Mann Whitney mengenai tingkat kepatuhan subjek dalam 
menghabiskan minuman karbohidrat elektrolit yang diberikan, tidak ada perbedaan hasil kerja antara pekerja yang menghabiskan minuman karbohidrat elektrolit $>75 \%$ dengan yang menghabiskan $50-75 \% \quad(p=0,866)$. Hal ini disebabkan terdapat faktor lain yang turut mempengaruhi produktivitas kerja seseorang yang belum diteliti pada penelitian ini. Faktor-faktor tersebut antara lain motivasi, masa kerja dan keterampilan kerja. Motivasi dipengaruhi oleh faktor yang berasal dari individu, seperti kehidupan ekonomi keluarga dan keinginan untuk memenuhi kebutuhan hidupnya. Faktor kedua yakni faktor yang berasal dari luar, seperti lingkungan kerja yang nyaman dan pemberian gaji yang sesuai dengan pekerjaan. ${ }^{26}$ Seseorang yang telah lama bekerja cenderung lebih fokus dan memiliki keterampilan yang lebih tinggi dalam melaksanakan tugasnya dibanding orang yang baru bekerja. $^{27}$

\section{SIMPULAN}

Pemberian minuman karbohidrat elektrolit berpengaruh terhadap produktivitas kerja pada pekerja garmen bagian penjahit setelah dikontrol asupan cairan, asupan energy dan usia. Minuman karbohidrat elektrolit meningkatkan jumlah pekerja yang produktif dari $14,28 \%$ menjadi $45,71 \%$.

\section{SARAN}

Pekerja harus mencukupi asupan energi sebesar $80-100 \%$ dari kebutuhannya dan perlu mempertahankan status gizi normal untuk menjaga performa tubuh saat bekerja. Selain itu perlu ditingkatkan kebiasaan mengkonsumsi minuman sebelum, selama dan setelah bekerja untuk mencegah kejadian dehidrasi pada pekerja yang aktif bekerja pada lingkungan panas. Perlu dilakukan penelitian mengenai pengaruh minuman karbohidrat elektrolit dengan varibel penelitian yang lebih bervariasi.

\section{UCAPAN TERIMA KASIH}

Penulis mengucapkan terima kasih pada subjek penelitian dan pihak CV. Eterna Garment Semarang yang telah bekerja sama dan membantu terlaksananya penelitian ini. Ucapan terima kasih disampaikan pula kepada dr. Apoina Kartini, M.Kes atas bimbingan yang telah diberikan, Prof.dr.HM. Sulchan,MSc.,DA.Nutr.,SpGk dan Binar Panunggal,SGz.,MPH atas kritik dan saran yang telah diberikan, teman-teman dan keluarga atas doa dan dukungannya.

\section{DAFTAR PUSTAKA}

1. Badan Pusat Statistik (BPS). Laporan Keadaan Ketenagakerjaan Indonesia. Edisi Agustus 2012. Badan Pusat Statistik. Jakarta.

2. International Labour Organization (ILO). Keselamatan dan Kesehatan Kerja di Indonesia. April 2004. ILO. Manila.

3. Tarwaka, Solichul HB, Lilik S. Ergonomi Untuk Keselamatan Kerja dan Produktivitas. Surakarta: Uniba Press; 2004. hal. 7-11, 67-70, 137-141.

4. Suma'mur. Ergonomi Untuk Produktivitas. Jakarta: CV Haji Masagung; 2001. hal. 84, 197.

5. Wolgemuth JC, Latham MC, Cesher A. Worker Productivity and The Nutritional Status of Kenyan Road Construction Laborers [serial online] 2002 [diakses 2 Mei 2013]. Tersedia dari: URL: http://www.ajcn.org

6. Brake DJ, Bates GP. Fluid Losses and Hydration Status of Industrial Workers Underthermal Stress Working Extended Shift [serial online] 2003 [diakses 1 Mei 2013]. Tersedia dari : URL: http://www.ncbi.nlm.nih.gov

7. Chara Biggs, Marie Paterson, Eleni Maunder. Hydration Status of South African Forestry Workers Harvesting Trees in Auntumn and Winter [serial online] 2010 [diakses 1 Mei 2013]. Tersedia dari: URL: http://www.ncbi.nlm.nih.gov

8. Melkie Edris. Nutrition for Health Extension Workers [serial online] 2004 [diakses 1 Mei 2013]. Tersedia dari: URL: http:// www.cartercenter.org

9. Robert W. Kenefick, Michael N. Sawka. Hydration at The Work Site [serial online] 2007 [diakses 1 Mei 2013]. Tersedia dari: URL: http://www.jacn.org

10. Institute of Medicine: Dietary Reference Intakes for Water, Potassium, Sodium, Chloride, and Sulfate. Washington, DC: The National Academies Press, 2005.

11. Graham P Bates, Veronica S Miller. Sweat Rate and Sodium Loss During Work in The Heat [serial online] 2008 [diakses 1 Mei 2013]. Tersedia dari: URL: http://www.ncbi.nlm.nih.gov

12. Kartasapoetra G, Marsetyo. Ilmu Gizi Korelasi Gizi, Kesehatan dan Produktivitas Kerja. Jakarta : Rineka Cipta; 2008. hal. 94-95

13. Atmadja Novita. Pengaruh Pemberian Minuman Formulasi Air Kelapa terhadap Kemampuan Rehidrasi dan Kelelahan Subjektif Pekerja [tesis]. Semarang : Universitas Diponegoro; 2011.

14. Mardiana. Pemberian Cairan Karbohidrat Elektrolit, Status Hidrasi dan Kelelahan pada Pekerja Wanita [tesis]. Semarang : Universitas Semarang; 2012.

15. Widajanti L. Survei konsumsi gizi. Semarang: Badan Penerbit Universitas Diponegoro. 2007; hal.41-5.

16. Skirbekk Vegard. Aged and Individual Productivity: A Literatur Survey [serial online] 
2003 [diakses 15 Mei 2013]. Tersedia dari: URL: http://www.demogr.mepg.de

17. Gibney Michael J, Ian A. Macdonald, Helen M. Roche. Nutrition and Metabolism, The Nutrition Society Textbook Series. Penerbit Blackwell; 2003. hal 30-40, 196

18. Madjid Amir S, Badriul H, Busjra MN, C Martin Rumende, Darlan Darwis, Hafis S, et al. Gangguan Keseimbangan Air - Elektrolit dan Asam-Basa. Jakarta: Balai penerbitan FKUI; 2007. hal. 43-44, 58-59

19. Price Sylvia A, Wilson Lorraine M. Patofisiogi Konsep Klinis Proses-proses Penyakit. Penerbit buku Kedokteran EGC; 2005. Edisi 6. Vol. 1. hal. 303-306

20. Mahan L. Kathleen, Silvia Escott-Stump, Janice L. Raymond. Krause's Food and The Nutrition Care Process. Misouri : Elseiver; 2012. hal.80, 587

21. Fink Heather Hendrick, Lisa A. Burgoon, Alan E. Mikesky. Practical Applications in Sports Nutrition. Massachusetts USA : Jones and Bartlett Publisher; 2006. hal.5-6, 158-169, 186-188, 193202

22. Stofan, John dan Robert Murray. Formulating Carbohydrate-Electrolyte Drinks for Optimal Efficacy. Dalam: Maughan J. R dan Robert Murray (editor). Sport Drink. Boca Raton-London-New York-Washington DC. CRC Press; 2001

23. Carter JM, Jeukendrup AE, Jones DA. The effect of carbohydrate mouth rinse on 1-h cycle time trial performance. Medicine and Science in Sports and Exercise ;2004. hal 36, 2107-2111

24. Williams, M. Nutrition for Health, Fitness and Sport. Eighth Edition. New York: America ; 2007.

25. Murray Bob. Hydration and Physical Performance [serial online] 2007 [diakses 29 Juli 2013]. Tersedia dari: URL://www.jacn.org

26. Winardi. Motivasi dan Pemotivasian Dalam Manajemen. Jakarta : PT Raja Grafindo Prasada ; 2004. hal 119

27. Robbins, Stephen P. Perilaku Organisasi. Jakarta : penerbit Prenhallindo ; 2003. Edisi Kesembilan. 